\title{
ANALYSIS OF PROFITABILITY, SIZE, BUSINESS RISK AND CAPITAL STRUCTURE IN THE COMPANY OF AUTOMOTIVE AND ALLIED PRODUCTS LISTED IN INDONESIA STOCK EXCHANGE FOR THE PERIOD OF 2013-2017
}

\author{
Insani Amalia Hasta, Istiqomah Sari Ratih Nur* \\ Department of Accounting, University of Airlangga, Surabaya, Indonesia \\ *E-mail: sariratihnur22@gmail.com
}

\begin{abstract}
This study aimed to determine the effect of profitability, company size, business risk to capital structure in the company of automotive and allied products listed in Indonesia Stock Exchange in the year 2013- 2017. The sample used in this study is the company of automotive and allied products. The analysis technique used is multiple linear regression analysis, classical assumption (normality test, multicoloniarity, autocorrelation test), hypothesis testing ( $F$ test, test determinant coefficient, $t$-test). Adjusted $R$-square value of 0.406 indicates that the variable capital structure can be explained by the variable profitability, firm size, and business risk only $40.6 \%$, while the remaining $59.4 \%$ is explained by other variables. The results of this study indicate that the variable profitability and business risk significant negative effect on capital structure, while the variable size of the company does not negatively affect the capital structure. This is because the big or small of the size of the company does not guarantee the smooth operations of the company with the interest of investors to invest their funds in the company.
\end{abstract}

\section{KEY WORDS}

Profitability, company size, business risk, capital structure.

PSAK No. 1 (2012) states that users of financial statements consist of potential investors, employees, lenders, companies and other creditors, customers, governments and their institutions, and the public. They use financial statements to meet several different needs. One investor, they need information to help determine whether to buy, hold, or sell the investment.

One component that can support the company's finances is funding that is used to finance the company's operational activities, especially those related to capital. The company must ensure that the capital structure obtained from internal and external funding is able to optimize funding so that there is no large debt and bankruptcy.

Yahdi and Puji (2014), said that the capital structure is an important first step in financing company activities. Companies must adjust operational activities to the company's goals by optimizing financing that can minimize capital and maximize the level of return (return) of the company, because when a company can increase its profitability, the company also provides benefits to the interests of the company and external parties (investors) and shareholders.

Profit is the difference in measurement of income costs. The size of the profit as a measure of asset growth depends on the accuracy of the cost measurement (Anis and Imam, 2007). Profit is often assumed to be a tool used to measure management performance.

One factor that influences the capital structure is profitability. Profitability is the ability to earn profits in a certain period. According to Bringham and Houston (2001), profitability is the net result of a series of policies and decisions. Profitability can also measure the effectiveness of the company's financial management with the profit generated. Yahdi and Puji (2014), companies that have a large rate of return tend to finance their operational activities with their own capital. This is because capital itself is considered more efficient and has a lower risk level than using external capital. 
The size of the company is a grouping to measure the scale of the company. Bambang (2001: 299), a large-sized company will be more daring to expand capital by investing in stocks to meet the company's funding needs compared to small companies.

Gitman (2009) in Seftianne and Ratih (2011), business risk is a risk that comes from companies that cannot finance the company's operations and are influenced by the stability of revenues and costs. Companies with high business risks avoid using external funds (debt) compared to companies with lower business risks.

\section{THEORETICAL BACKGROUND AND HYPOTHESES DEVELOPMENT}

Pecking order theory is a theory that explains the hierarchy of preferred sources of funds. This theory prefers companies to use internal funds to meet the operational needs of the company rather than using external funds, namely debt (Suad and Enny, 2012). If internal funding is insufficient, the company uses retained earnings then debt. This is done to minimize the costs and problems that arise from external funding contracts, namely debt.

Trade off theory is a theory that balances the benefits of funding with high interest rates and high bankruptcy costs. This theory explains that increasing debt to the capital structure will increase the value of the company by the tax rate multiplied by the amount of debt (Ade, 2011). The capital structure policy involves a trade off between the risks borne by the shareholders and the rate of return expected by the shareholders. Optimal capital structure is better in the balance between risk and rate of return that can maximize stock prices.

The capital structure of a company generally consists of several components, namely (Bambang, 2001):

- Foreign capital means capital originating from outside the company that is temporary for the company's operations which are usually referred to as a company that has a maturity date. Foreign capital originating from outside the company can be assumed to be a loan from creditors by selling securities;

- Own capital means capital that comes from the owner of the company that is embedded in the company for an indefinite time. This capital will be borne by the overall risk of the company and the capital that guarantees creditors.

According to Bringham and Houston (2011: 39), factors that influence the company's capital structure include:

- Sales stability means that relatively stable company sales can get more loans and bear a high fixed burden compared to companies with unstable sales.

- Asset structure means that companies whose assets are suitable to be used as credit guarantees tend to use more debt.

- Leverage operations means companies with smaller operating leverage tend to be better able to increase financial leverage because the company has a small business risk.

- The growth rate means that companies that experience rapid growth require more funding from external sources and face great uncertainty.

- Profitability means companies that have a high level of return on investment relative to using smaller debt. This high level of return allows the company to finance most of its operational needs with its own capital.

- Tax means that interest is a deductible expense for corporate tax purposes. However, the higher the corporate tax rate, the greater the benefits of using debt.

- Control means that the influence of the opponent's debt on the position of management control can affect the capital structure.

- Management attitude means that management can consider itself to make decisions about the right capital structure in terms of the use of external funds.

- The attitude of lenders and rating agencies often influences the decision of the company's financial structure. 
- Market conditions mean that conditions in the stock market and securities that can experience long-term or short-term changes greatly affect the optimal capital structure of the company.

- The company's internal condition means that if the company predicts high profit and the increase is anticipated by investors because it has not been reflected in the stock price, then the company prefers financing with debt compared to issuing shares.

- Financial flexibility means that a smart manager can always provide a lot of capital to finance the company's operational activities so that the company is more productive.

Kasmir (2013), profitability is a ratio to assess the company's ability to seek profit. This ratio also provides a measure of the level of management effectiveness of a company. Profitability is an illustration of the management's performance in managing the company and is used to determine the efficiency of the company doing production.

Company size is a scale for classifying a company. The size of the company is seen from the total assets owned by the company, if the company has a large total assets it will give management authority to use these assets. Dicky and Sri (2012), the size of the company is the amount of assets owned by the company. Company size is calculated by the natural logarithm formula of total assets.

Gitman and Zutter (2012) in Linda and Aan (2013), the definition of business risk is the risk of a company that cannot cover operating costs that are affected by the stability of costs and income. Saidi (2004), business risk is an uncertainty experienced by a company in carrying out its business activities to finance the company's operational activities.

Capital structure is one of the most important elements that determine the good and bad performance of the company, because the capital structure will regulate and determine the funding sources and expenditures made by the company to finance its operational activities. The capital structure is a balance between long-term debt and own capital owned by the company. Improved capital structure in the business world is an obligation to increase efficiency and survive to compete with other companies.

Sofyan (2013), profitability ratios describe the ability of a company to earn profits through all capabilities, and sources such as sales, cash, capital, and number of employees. This ratio is used to compare the value of the company's profit from the previous year with the current year, so that company management can find out the financial development, funds and assets of the company, both significant decreases and increases.

Based on research conducted by Mouamer (2011) in Yahdi and Puji (2014), it shows that there is a negative influence between profitability and capital structure. This is adjusted to the pecking order theory, where companies that have high profitability and generate high income are expected to use less debt than companies with low income. Companies that have high income borrow small amounts of external funds because the company already has sufficient internal funds to finance the company's operational activities.

$\mathrm{H} 1$ : Profitability has a negative effect on the capital structure.

The size of a company can be seen based on the total value of assets owned by the company. The higher the total asset value, the greater the size of the company and the more attention it gets from the public and investors. The size of the company also determines how much the company uses external funding.

Based on research conducted by Glenn, Herlina, and Rina (2011) shows that there is a positive influence between firm size and capital structure. This is adjusted to the trade off theory, where companies with large size companies are increasingly using debt. The low risk obtained by the company will encourage companies to use more debt compared to smaller companies.

H2: Firm size has a positive effect on capital structure.

Brigham and Houston (2007) in Dicky and Sri (2011), business risk is how much the company's stock risk is when using large debt. Companies should be more aware of the existence of debt so that the business risks obtained are getting smaller, companies that have large business risks suddenly use less debt than companies that have small business risks. 
Based on research conducted by Linda and Aan (2013), business risk affects the capital structure. This is because, if the company has a high business risk, it tends to use substantial external funding such as debt or issuing new shares. The external funding company is caused by investors considering that companies that have high business risk will also provide high returns. But the smaller the business risk can lead to a more optimal capital structure, whereas the greater the business risk, the smaller the capital structure of the company will be.

H3: Business risk affects the capital structure.

\section{METHODS OF RESEARCH}

The population in this study was automotive and allied products companies listed on the Indonesia Stock Exchange during the period 2013-2017. The population was chosen because the company was always productive and the products produced by the company became the needs of the Indonesian people and the products produced were always in demand by the public. When the demand for purchases of motorized vehicles increases, more and more parts are needed. Therefore the researchers want to know the development of automotive and allied products in the ASEAN free trade (MEA) 2015 will continue to grow and survive or will experience a decline in sales due to the phenomenon of fuel price increases in early 2015.

Sampling in this study uses purposive sampling method with several criteria that have been determined by researchers. The following are purposive sampling criteria: (1) Automotive and allied products companies that issue financial statements for the period 2013-2017, (2) Companies whose financial statements use rupiah, (3) Companies that do not carry out economic events, such as: acquisition , merger, and delisting for the 2013-2017 period, (4) The company has complete data related to the independent variables of the study, namely: profitability proxied by ROA, size of the company proxied by In total assets, business risk proxied by EBIT standard deviation divided by total assets, and capital structure proxied by long-term debt divided by own capital.

Of the 18 companies listed as automotive and allied products on the Indonesia Stock Exchange, 12 companies were selected as samples of selected companies based on purposive sampling and studied for five years, so there were 48 samples.

This study took a sample of automotive and allied products that had been categorized through purposive sampling for the 2013-2017 period. The data used in this study are secondary data derived from the annual report of automotive and allied products listed on the Indonesia Stock Exchange for the period 2013-2017. Data collection techniques for the purposes of this study were carried out with documentation. The type of data in this study is quantitative data. The data was obtained from the Indonesian Capital Market Directory (ICMD) and www.idx.co.id.

The research variables used in this study include the dependent variable namely the capital structure and the independent variables consisting of profitability, company size and business risk.

Variable Operational Definition. Capital structure is the capital structure is one of the most important elements that determine the good and bad performance of the company, because the capital structure will regulate and determine the funding sources and expenditures made by the company to finance its operational activities.

Kasmir (2013), profitability is a ratio to assess the company's ability to seek profits Profitability in this study is calculated using the formula of return on assets (ROA). ROA is a measurement of the company's ability to generate profits with the total assets of the company. The higher this ratio indicates that the better the state of a company.

Company size is a scale to classify a company. According to Glenn, Herlina, and Rini (2011), given the large asset value of a company, the process of calculating the size of the company, the total value of assets is calculated by the natural logarithm (Ln) formula. 
Business risk is the uncertainty faced by the company in running its business. The higher the business risk of a company can reduce debt. In this study business risk will be measured using the EBIT standard deviation divided by total assets.

Analysis Tool. To examine the relationship between profitability, firm size, and business risk to the capital structure of automotive and allied products listed on the IDX 2013-2017, multiple linear regression models were used. Multiple linear regression analysis technique is used to examine the extent to which the independent variables influence the dependent variable. The analysis used to test the equation is mathematically formulated as follows:

$$
S M=\alpha+\beta_{1} \text { PROFIT }+\beta_{2} \text { SIZE }+\beta_{3} \text { BRISK }+e
$$

Where:

SM: Capital Structure;

$\alpha$ : Constanta of regression equation;

$\beta_{1,2,3}$ : Regression coefficients on each variable;

PROFIT: Profitability;

SIZE: Size;

BRISK: Business Risk;

e: Error term.

\section{RESULTS AND DISCUSSION}

Descriptive analysis is used to provide an overview of the variables in this study, namely the variable capital structure, profitability, firm size, and business risk.

Table 1 - Results of Descriptive Analysis for Five Years (2013-2017)

\begin{tabular}{|c|c|c|c|c|c|}
\hline Variabel & $\mathrm{N}$ & Minimum & Maksimum & Rata-rata & Std. Deviasi \\
\hline Profitabilitas & 60 & $-0,0861$ & 0,3246 & 0,0956 & 0,0680 \\
\hline Ukuran perusahaan & 60 & 11,1396 & 14,3304 & 12,5263 & 0,8406 \\
\hline Risiko bisnis & 60 & 0,0368 & 47,2760 & 7,3793 & 11,5878 \\
\hline Struktur modal & 60 & 0,0118 & 4,7513 & 0,6075 & 0,9021 \\
\hline
\end{tabular}

Source: SPSS.

The table above shows the results of the descriptive analysis of the dependent variable (capital structure) represented by SM and independent in this study (profitability, firm size, and business risk), each of which is represented by PROFIT, SIZE, and BRISK.

From the results of the descriptive analysis can be seen the dependent variable of this study is the capital structure measured using long-term debt divided by own capital which has varied or heterogeneous data for five years of observation. This can be seen from the mean number which is smaller than the standard deviation number. It can be seen that the minimum value in the capital structure is 0.0118 which is owned by PT. Astra Otoparts Tbk in 2016, which means that companies tend to use their own capital to finance the needs and operations of the company so that the company can get maximum profit without having substantial debt. While the maximum value in the capital structure is 4,7513 owned by PT. Indomobil Sukses Internatioanl Tbk in 2013, which means that the company uses more external funding, namely debt rather than its own capital to meet the funding needs of the company so that the development and growth of the company gets better, but the greater the debt that the company has, the lower the profit generated by the company,

The next variable is the independent variable profitability which is proxied by ROA which is the ratio to assess the company's ability to find profit in a certain period that has data that is not variable or homogeneous during the five years of observation. This can be seen from the mean number which is greater than the standard deviation number. It can be seen that the minimum value on profitability is -0.0861 owned by PT. Prima Alloy Steel Tbk in 2013, which means that the company has poor profitability compared to other automotive and allied products companies. While the maximum value of profitability is 0.3246 owned by 
PT. Indospring Tbk in 2016, which means that the company has good ability to generate profits compared to other companies.

The next independent variable is the size of the company measured using the natural logarithm (In) of total assets. This variable has data that is not variable or homogeneous for five years of observation. This can be seen from the mean number which is greater than the standard deviation number. It can be seen that the minimum value on the size of the company is 11,1396 owned by PT. Multi Prima Sejahtera Tbk in 2013, which means that the company is a small company that has limited assets so that it can hamper the company's operations. While the maximum value of the company size is 14,3304 owned by PT. Astra International Tbk in 2017, which means that the company is a large company that has large assets and external funding that can meet its operational needs for the development of the company.

The last independent variable is business risk measured using the EBIT standard deviation divided by total assets. This variable has varied or heterogeneous data. This can be seen from the mean number which is smaller than the standard deviation number. It can be seen that the minimum value on business risk is 0.0368 owned by PT. Astra International Tbk in 2017, which means that investors tend to get smaller business risks from the company. And companies can get funds from investors to finance operations and other needs because investors get a small business risk from the company. While the maximum value on business risk is 47.2760 owned by PT. Multi Prima Sejahtera Tbk in 2015, which means that investors get a large business risk that is obtained from the investment results in the company. This means that if the company provides a large business risk, the company uses more external funding, namely debt and issuing new shares.

Table 2 - Regression Result

\begin{tabular}{|c|c|c|c|c|}
\hline Variabel & Coefficient Regression & Standard Error & t Count & Sig. \\
\hline Constanta & 2,948 & 2,030 & 1,452 & 0,152 \\
\hline Profitability & $-8,360$ & 1,367 & $-6,114$ & 0,000 \\
\hline Size & $-0,104$ & 0,158 & $-0,662$ & 0,511 \\
\hline Business Risk & $-0,032$ & 0,011 & $-2,787$ & 0,007 \\
\hline $\mathrm{R}^{2}$ & 0,436 & & & \\
\hline Adjusted $\mathrm{R}^{2}$ & 0,406 & & & \\
\hline F Count & 14,440 & & & \\
\hline Sig.F & 0,000 & & & \\
\hline
\end{tabular}

Source: SPSS.

The results of the SPSS output indicate that the results of the SPSS output show an F count of 14.440 and a significance of 0.000 . This shows that the significance value $<0.05$ which means $\mathrm{HO}$ is rejected, and it can be concluded that the regression model is good (fit) and can be stated that profitability, company size and business risk together influence the capital structure. From table 2 it can be seen that the value of Adjusted R Square is 0.406 or $40.6 \%$, which means that the capital structure variable can be explained by the variables of profitability, company size, and business risk by $40.6 \%$, while the remaining $59.4 \%$ is explained by other variables or other models outside the independent variables studied. Standard Error of estimate (SEE) is 0.6952553513 , which means that the smaller the SEE value will make the regression model more precise in predicting the dependent variable (capital structure).

The table above also shows that there are two independent variables that exist in the regression model namely profitability (PROFIT), and business risk (BRSIK) which have a significant negative effect. This can be seen from the significance value of the PROFIT variable of 0.000 and BRISK of 0.007 , where the two signatures are below 0.05 . There is also one independent variable that is firm size (SIZE) which has no effect, it can be seen from the significance value for SIZE of 0.511 which means that the significance value is above 0.05 . From these results it can be concluded that in the regression model in this study 
the capital structure is influenced by profitability (PROFIT), and business risk (BRSIK) with the equation obtained, namely:

$$
\mathrm{SM}=2,948-8,360 \text { Profit }-0,104 \text { Size }-0,032 \text { Brisk }
$$

The following is the interpretation of the regression coefficient above, namely: (1) The constant is 2.948 which means that if the independent variable (profitability, firm size, and business risk) is considered constant, then the capital structure is 2.948, (2) Profitability is 8,360 which means that if the profitability variable is one unit, then profitability will decrease by 8.360 , (3) Business risk by -0.032 , which means that if the business risk variable is one unit, the business risk will decrease by 0.032 .

The Effect of profitability on capital structure. Profitability is the company's ability to generate profits with capital or company assets. Profitability can affect the capital structure because when a company is able to generate large profits, the company can also finance the operational needs of the company using the company's internal funds. This shows that companies use more internal funds, and companies can reduce the use of external funds, namely debt. This is consistent with the theory used in this study, namely the pecking order theory which states that companies prefer to finance the needs of companies with internal funds rather than external funds, namely debt. Therefore when the profitability of large companies can make the company's capital structure decline.

The results of this study contradict the research conducted by Dicky and Sri (2011) which states that profitability does not affect the capital structure. But the results of this study are in line with the research conducted by Glenn, Herlina, and Rini (2011) which states that profitability has a significant negative influence on capital structure. Because companies prefer to use earnings to hold as a source of funding. Thus the greater the profit generated by the company, the greater the costs that can be used to finance funding needs from retained earnings and the rest can be used to pay debt repayments so that the debt that the company has will be smaller. The results of this study are also supported by research from Mutmaminah (2003) in Dicky and Sri (2011) which states that the existence of a negative relationship between profitability and capital structure is due to profitability being the main indicator that the company has sufficient internal funds for funding.

By means of internal funding, companies can provide a high rate of return on investments that make debt smaller. The rate of return is used to finance funding needs, so managers prefer if financing needs through retained earnings, then debt, and finally the sale of new shares.

So it can be concluded that the higher profitability of the company will make the capital structure smaller. This is because high profitability can make company managers use internal funding from retained earnings to finance operational needs. Because profitability is the size of a company to be able to have sufficient internal funds for funding.

The Effect of company size on capital structure. Company size is a scale to classify a company. Company size is the size of assets owned by a company, the size can be seen based on the total assets owned by the company. The size of the company has no effect on the capital structure because the size of the company cannot determine the smooth funding of the company's needs and the capital structure of the company. The results of the t-test statistical test for firm size show that $\mathrm{H}_{02}$ is accepted which means there is no influence on the capital structure.

The results show that the size of the company does not affect the capital structure. This proves that the large size of the company does not guarantee the smooth operation of the company. This is contrary to the results of research conducted by Dicky and Sri (2011) which states that firm size has a negative influence on the capital structure. But the results of this study are in line with research conducted by Friska (2011) which states that firm size does not affect the capital structure. The size of the company does not guarantee the survival of the company and the smooth funding of operational activities, and the size of the company cannot guarantee investors' interest to invest in the company. 
So it can be concluded that the size of the company is not one of the factors that can affect the capital structure. When investors want to invest in a company, investors look more at the level of profitability produced by the company rather than looking at the size of the company. If the company is large but has little profitability and more capital structure, investors will be reluctant to invest because investors will think if the company cannot provide high returns to investors. And vice versa, if the company is small in size but the profitability is large and the capital structure is smaller, investors will consider investing in the company because the profitability of the company is quite attractive. And the size of the company cannot be a factor that can affect the capital structure.

The effect of business risk on the capital structure. Business risk is the basic risk that a company has in addition to financial risk as an additional risk to the company due to the use of debt to finance operational activities. Business risk is the uncertainty faced by the company in running its business. Business risk can affect the capital structure because companies that have high business risk tend to use internal funds rather than external funds. The company uses internal funds more because the company generates large profits and can fulfill its operational activities without using too much debt. This is in accordance with the pecking order theory which states that companies prefer to use internal funds rather than external funds.

The results of this study are not in line with the research conducted by Saidi (2004), and Friska (2011) which states that business risk does not affect the capital structure. But the results of this study are in line with the research conducted by Pramistha and Toto (2012) which states that business risk has a significant negative effect on capital structure. This means that if a company that has high business risk tends not to use external funds to finance the company's operations but with internal funds, namely its own capital, the company's capital structure tends to be small. While it should be noted that the high and low business risks can be seen from the variability of demand, price, input costs.

Companies that have high business risk tend to use less external funding, because if the company uses a small amount of debt, the company will provide a high business risk. That signifies a high level of business risk that will automatically impact high corporate profits. So if the company's profits are high, the company can manage internal funding well without funding the company's operations through debt. When a company has sufficient internal funds, the company does not need to use loans to finance operational activities, the company can use internal funds to reduce the risk of a larger debt, so the company's capital structure is smaller.

So it can be concluded that business risk has a significant negative effect on the capital structure or can be said to be inversely proportional. The company provides a high business risk which indicates that the company's profits show an increase and companies can use internal funds to finance operations without using debt, therefore the company's capital structure is smaller even though the business risks are high.

\section{CONCLUSION}

This study aims to examine the effect of profitability, firm size, and business risk on the capital structure of automotive and allied products listed on the Indonesia Stock Exchange in 2013-2017. This study uses the dependent variable, namely the capital structure. Sampling was carried out based on the purposive sampling criteria which resulted in 12 companies in the automotive and allied products industry listed on the Stock Exchange during 2013-2017 so that the number of samples was 60 data.

The data used in this study were obtained from information on corporate financial reports and Indonesian Capital Market Directory (ICMD), as well as Indonesian Stock Exchange (IDX). Testing in this study was carried out with SPSS 20.0, which uses the classic assumption test and multiple linear regression analysis consisting of normality test, multicolonierity test, autocorrelation test, $F$ test, determinant coefficient test (R2), and test.

Based on the simultaneous influence test ( $F$ test) shows that the regression model is

fit, ie the model is used to predict profitability, firm size, and business risk to the capital 
structure and can be stated that the independent variables together affect the dependent variable (capital structure ) Based on the results of the determinant coefficient (R2) shows that the independent variables (profitability, firm size, and business risk) can explain the dependent variable (capital structure) by $40.6 \%$, but still unable to explain the dependent variable. Furthermore, the results of multiple linear regression analysis from the partial test (ttest) show that (a) the profitability variable has a significant negative effect on the capital structure. This significant negative influence means that if the profitability generated by the company is greater then the company's capital structure gets smaller. The results of this study are in line with the research conducted by Glenn, Herlina, and Rini (2011) which states that profitability has a significant negative effect on capital structure, (b) Variable firm size does not affect the capital structure. The meaning of these results is that the large size of the company does not guarantee the smooth operation of the company which cannot determine whether the company's capital structure is getting smaller or larger. The results of this study are in line with research conducted by Friska (2011) which states that firm size does not affect the capital structure, (c) Business risk variables have a significant negative effect on capital structure. This means that the company provides a high business risk indicating that the company's profits increase and the company uses internal funds to finance operations without using debt, therefore the company's capital structure is smaller even though the business risks are high. The results of this study are in line with the research conducted by Pramistha and Toto (2012) which states that business risk has a significant negative effect on capital structure.

Limitations in this study include (1) The number of sample companies in this study only used 12 companies from 18 companies selected from the sampling criteria, and (2) In this study the measurement of business risk using EBIT standard deviation of all automotive and allied products companies.

Based on the limitations of the study, the suggestions that can be given by researchers for future research so that further researchers are expected to continue this research by adding liquidity variables and replacing the company size variables with managerial ownership or new variables that are expected to influence the capital structure so that it can cover a wider range of his research. Then so that further research is expected to expand the company's sample as a whole not only in automotive and allied products but in other industrial sectors that have a large sample of companies in order to obtain more complete data with a larger number of samples, and so that further research is expected to be able to use business risk measurement using EBIT standard deviations per company in order to know the business risks obtained from each company.

\section{REFERENCES}

1. Ade Gunawan. 2011. "Pengaruh Profitabilitas dan Perputaran Aktiva Terhadap Struktur Modal". Jurnal Manajemen \& Bisnis. Vol 11, No.01, April 2011.

2. Anis Chariri dan Imam Ghozali. 2001. Teori Akuntansi. Edisi 1.Semarang: Badan Penerbit Universitas Diponegoro.

3. Bambang Riyanto. 2001. Dasar-Dasar Pembelanjaan Perusahaan. Yogyakarta:BPFE Yogyakarta.

4. Dicky Dwi Cahyono dan Sri Adji Prabawa. 2011. "Pengaruh Ukuran Perusahaan, Profitabilitas, Pertumbuhan Aset, dan Risiko Bisnis Terhadap Struktur Modal pada Perusahaan Manufaktur yang Terdaftar di BEI Periode 2008-2012". Jurnal Ilmiah Manajemen. Vol 10, No. 01, April 2011.

5. Eugene F. Brigham dan Joel F. Houston. 2001. Manajemen Keuangan. Edisi 8. Jakarta: Penerbit Erlangga.

6. Friska Firnanti. 2011. "Faktor-Faktor yang Mempengaruhi Struktur Modal Perusahaan Manufaktur di Bursa Efek Indonesia". Jurnal Bisnis dan Akuntansi. Vol. 13, No.02, Tahun 2011. Agustus. Hal 119-128.

7. Glenn Indrajaya, Herlina, dan Rini Setiadi. 2011. "Pengaruh Struktur Aktiva, Ukuran Perusahaan, Tingkat Pertumbuhan, Profitabilitas dan Risiko Bisnis Terhadap Struktur 
Modal: Studi Empiris pada Perusahaan Sektor Pertambangan yang Listing di Bursa Efek Indonesia Periode 2004-2007". Akurat Jurnal Ilmiah Akuntansi. No. 06, Tahun k2-2 September-Desember 2011.

8. Ikatan Akuntansi Indonesia. 2012. Standar Akuntansi Keuangan per 1 juni 2012. Jakarta: Ikatan Akuntansi Indonesia.

9. Kasmir. 2013. Analisis Laporan Keuangan. Jakarta: Raja Grafindo.

10. Linda Wimelda dan Aan Marlinah. 2013. "Variabel-Variabel yang Mempengaruhi Struktur Modal pada Perusahaan Publik Sektor Non Keuangan". Media Bisnis. November.

11. Mochamad Yahdi Khairin dan Puji Harto. 2014. "Pengaruh Growth Opportunity, Profitabilitas, Fixed Asset Ratio dan Risiko Pasar Terhadap Struktur Modal". Diponegoro Journal of Accounting. Vol 03, No. 02, Tahun 2014. Hal 1-12.

12. Pramistha Ayu Nelvistiarindah dan Toto Rahardjo. 2012. "Pengaruh Variabel Struktur Aktiva, Risiko Bisnis, Net Profit Margin dan Firm Size Terhadap Struiktur Modal (Studi pada Perusahaan Farmasi yang Terdaftar di BEI Periode 2008-2012).

13. Saidi. 2004. "Faktor-Faktor yang Mempengaruhi Struktur Modal pada Perusahaan Manufaktur Go Public di BEJ Tahun 1997-2002. Jurnal Bisnis dan Ekonomi. Vol. 11, No.01, Tahun 2004. Maret. Hal 44-58.

14. Seftianne dan Ratih Handayani. 2011. "Faktor-Faktor yang Mempengaruhi Struktur Modal pada Perusahaan Publik Sektor Manufaktur". Jurnal Bisnis dan Akuntansi. Vol. 13, No. 01, Tahun 2011. April. Hal 39-56.

15. Sofyan Safri Harahap. 2013. Analisis Kritis Atas Laporan Keuangan. Edisi 11. Jakarta: PT. Raja Grafindo Persada. Hal 304-305.

16. Suad Husnan dan Enny Pudjiastuti. 2012. Dasar-dasar manajemen keuangan. Edisi 4. Yogyakarta: UPP STIM YKPN. 